\title{
An Empirical Study on Measuring the Association between Job Status of Individuals and their Current Financial Condition
}

\author{
V. Santhi ${ }^{1 *}$, R. Sudha ${ }^{2}$ and Aishwariya Sankaranarayanan ${ }^{3}$ \\ 'Associate Professor, Department of Humanities, PSG College of Technology, \\ Coimbatore, Tamil Nadu, India; link2santhi@gmail.com \\ ${ }^{2}$ Assistant Professor, Department of Commerce, PSG College of Arts and Science, \\ Coimbatore, Tamil Nadu, India; sudha.shamu@gmail.com \\ ${ }^{3}$ Pursuing MBA in International Marketing, Management Development Institute of Singapore, Singapore
}

\begin{abstract}
Job status of individuals is generally applied as a determinant in measuring their financial status. The job is linked with the salary earned by an individual, who is a part of any family household. This study aims to measure the association that prevails between job status of individuals and their current financial condition. The study confirms the fact that, influences of job on the employees' including private sector workers' life-style and socio-economic status are more related to emotional feel. The study suggests that wise investment pattern and strategic financial planning can support both self-employed persons and employees working in either public or private sectors in enhancing their current financial conditions.
\end{abstract}

Keywords: Financial Conditions, Financial Literacy Level, Financial Status, Job Status

\section{Introduction}

Job status of individuals is generally applied as a determinant in measuring their financial status. The job is linked with the salary earned by an individual, who is a part of any family household. Salary is a fixed amount of money or compensation paid to an employee by an employer in exchange for a productive work performed. Remuneration system plays an important role in determining an employee's level of job satisfaction. The growing needs of families with higher living costs force workers to seek higher income that can guarantee their future and life satisfaction. If individuals believe they are not compensated well, a state of emotional dissatisfaction will develop. This emotional discrepancy grows and accumulates over time, thus makes employees feel unhappy and dissatisfied working for the organisation ${ }^{1}$.
Finance is the important resource to every individual and every organization. As for as individuals are considered, they need money to meet out their day to day financial requirements, they have to save money for better tomorrow and save money for emergency situations. In short salary appears to represent one of the forerunner conditions of the general satisfaction. Many of the economists claim that Socioeconomic Status (SES) is an economic and sociologically combined total measure of a person's work experience and of an individual's or family's economic and social position in relation to others, based on income, education, and occupation. When analyzing a family's socio economic status, the household income, earners' education, occupation, as well as combined income, varies with each individual, when their own attributes are assessed or more commonly known to depict an

${ }^{*}$ Author for correspondence 
economic difference in the society as a whole. To draw an empirical justification to this concept the present study was conducted.

\section{Review of Literature}

Cohen and Sebstad ${ }^{2}$ mentioned that the financial education can play an important role in reducing poverty in developing countries by building people's knowledge and skills in optimal usage of resources and making optimal financial and economic decisions related, but not limited to savings, investments ,and wealth accumulation which essentially facilitate. Joo and Grable ${ }^{3}$ in their study aimed at determining the factors that influence financial satisfaction. The survey results showed that educational level, financial literacy, risk, financial ability, financial activity and financial pressures have a direct impact on financial satisfaction. Tedeschi and Calhoun ${ }^{4}$ exposed that financial concerns usually consist of emotions like fear and anxiety which can negatively affect the human and make positive changes such as finding new jobs and improve the ability to manage the financial issues. Neill et al., ${ }^{5}$ examined the relationship between financial activities, financial wellbeing, and health among 3,121customers of a financial consulting organization. Their results showed that people with higher income and financial well-being experienced less stress, were more motivated in financial activities, had better family relationships and remained physically and mentally healthier. Caskey ${ }^{6}$ suggested that improvement in personal financial capability leads to better management of one's financial affair and improved socioeconomic well being. Tamimi et al., examined the impact of financial literacy on financial decisions. Their results showed that the field of individual activities affected financial literacy level and people who invested in the areas of banking and stock possessed higher level of financial literacy. The exploratory study by Holzman ${ }^{8}$ aimed at bringing out wisdoms of personal financial capability from high income and developed countries to low and middle income countries. $\mathrm{Cude}^{9}$ examined effective factors on people's financial literacy. His results showed that higher level of education, risk appetite, higher age, more work experience, family income, parental occupation and attending the training classes increased the financial literacy. McCarthy ${ }^{10}$ also revealed that behavioral factors like self-control, planning and patience affected the ability to manage personal finance and stay out of financial trouble. Marican et al., ${ }^{11}$ concluded that job performance and work productivity has strong association with financial stress faced by the employees.

\section{Statement of the Problem}

The presence or absence of certain material items, such as home, cars, jewels are commonly associated with standard of life. The ability to spend money for entertainment, health, education, variety in life, art, music and travel also contribute to the standard of life. Large expensive or fancy items are viewed as evidence of high standard of living. The standard of living is generally associated with the job status of individuals. Based on this concept the present study aims at measuring the association that prevails between job status of individuals and their current financial condition.

\section{Objectives of the Study}

- To study the demographic status of the households living in Coimbatore city.

- To measure the association between job status of individuals and their current financial condition, which in turn is influenced by their financial literacy levels, current financial conditions, nature of saving and investment practices and the financial discipline practices.

\section{Hypotheses of the Study}

In tune with the above objective of measuring the association between job status of individuals and their current financial condition, the following alternative hypotheses were framed and tested wherein the financial literacy level, current financial condition, nature of savings and investment practices, and financial discipline practices of the households are considered as independent variables and their perception on influences of job on their financial status is considered as dependent variable.

$\mathrm{H}_{1}$ 1: There exists close association between financial literacy level of households (FINLT) and their perception on influences of job on their financial status (IJOFC).

$\mathrm{H}_{1}$ 2: There exists close association between current financial conditions of households (CFINC) and their perception on influences of job on their financial status (IJOFC).

$\mathrm{H}_{1}$ 3: There exists close association between nature of savings and investment practices of households (NOSAI) and their perception on influences of job on their financial status (IJOFC).

$\mathrm{H}_{1} 4$ : There exists close association between financial discipline practices of households (FINDP) and their perception on influences of job on their financial status (IJOFC). 


\section{Research Methodology}

The study was conducted among the households residing in Coimbatore city, Tamil Nadu. Current study is descriptive in nature. Small sample of sixty respondents were chosen for this study based on convenience sampling method.

\section{Tools of Analysis}

Data analysis was made by employing the following statistical tools:

Percentage analysis: It is the first and basic tool used in any study relating to subjects of social sciences. It is mainly used to assess the distribution of respondents under each category. As it is expressed in percentage it facilitates comparison. In this study it is used to find out the distribution of the profile of the respondents, their financial literacy and nature of saving and investment practices among the respondents.

Structural Equation Model: Structural Equation Model can be viewed as a combination of factor analysis and regression analysis and it is used to analyze the structural relationship between measured variables and latent constructs. The structural equation model implies a structure for the covariance between the observed variables. Structural Equation modeling however relies on several statistical tests to determine the adequacy of model fit to the data. The chi-square test indicates the amount of difference between expected and observed covariance matrices. A model is considered a good fit if the value of the chisquare test is significant.

\section{Results and Discussion}

The demographic and socio-economic profile of the sample households in Coimbatore city exhibited in Table 1 reveals that out of 60 respondents surveyed, majority of 60 per cent of them were female and 40 per cent were male; 40 per cent of them were aged between 21-30 years and another 40 per cent were under the age group of 31-40 years, 10 per cent of them were aged between 41 and 50 years and another 10 per cent were above 50 years of age; 80 per cent of them were married and the rest of 20 per cent were unmarried; 30 per cent of them were post graduates and another 30 per cent were graduates, 26.7 per cent were diploma holders and the rest of 13.3 per cent possessed other categories of education; 63.3 per cent of them were employed in the private sector, 10 per cent were public sector employees and 26.7 per cent were professionals; 30 per cent of the sample house holds' monthly income was ranging from
Rs.10000-20000, 30 per cent of the respondents' monthly income was ranging from Rs.20001-30000, 13.3 per cent of the respondents' monthly income was ranging from Rs.30001-40000 and 26.7 per cent of the respondents were earning more than Rs. 40000 per month.

Table 2 indicates that out of 60 respondents surveyed, 36.67 per cent of them possessed reasonable knowledge on the effective management of saving and investment; 23.33 per cent of them were well aware of the effective saving and investment management practices; 10 per cent of them had a very high level of financial literacy and the remaining 30 per cent of them were lacking proper financial literacy.

From Table 3, it can be inferred that all the 100 per cent of the respondents were holding saving bank accounts which of course was after the implementation of "Pradhan Mantri's Jan Dhan Scheme" by the Central Government of India. Whereas 33.33 per cent of the respondents had invested in own life insurance policies and 30 per cent of them had invested in share market. Further 26.67 per cent of the respondents had invested in mutual funds, 23.33 per cent of them owned post office savings, 16.67 per cent had invested their money in private chits, 16.67 per cent in real estate and another 16.67 per cent in gold/bullions. Also it can be observed that 6.67 per cent of the respondents owned bank deposits (fixed /recurring) and another 6.67 per cent of them had invested in national saving certificates.

The result of the study shown in Table 4 confirms that the proposed model has a reasonable data fit $\chi^{2}=78.560(\mathrm{p}=.000), \mathrm{GFI}=.756, \mathrm{AGFI}=.390, \mathrm{TLI}=.294$, $\mathrm{CFI}=.577, \mathrm{NFI}=.567, \mathrm{PNFI}=.340, \mathrm{PCFI}=.346, \mathrm{RFI}=.278$, $\mathrm{IFI}=.586$, RMSEA $=.000$. It is therefore concluded that there exists close association between financial literacy level of households, their current financial conditions, nature of saving and investment practices and financial discipline practices, and that of the households' perception on influences of job on their financial status. All the four hypotheses framed stands accepted.

The measure of co-efficient of variances disclosed in Table 5 reveals that financial literacy $(\beta=.149, \mathrm{p}=.003)$, current financial condition $(\beta=-.990, p=.000)$, nature of saving and investment $(\beta=3.265, \mathrm{p}=.000)$ and financial discipline practices adhered by the households $(\beta=-2.421, \mathrm{p}=.000)$ are significant. Thus all the four hypotheses $\mathrm{H}_{1} 1, \mathrm{H}_{1} 2, \mathrm{H}_{1} 3$ and $\mathrm{H}_{1} 4$ framed stand accepted.

\section{Findings}

It is observed that out of 60 respondents surveyed, 36.67 per cent of them possessed moderate financial literacy, 
Table 1. Profile of the respondents

\begin{tabular}{|c|c|c|c|c|}
\hline S. No & Den & raphic variables & No. of. & Percentage \\
\hline 1 & Age(Years) & $21-30$ & 24 & 40.0 \\
\hline & & $31-40$ & 24 & 40.0 \\
\hline & & $41-50$ & 6 & 10.0 \\
\hline & & Above 50 & 6 & 10.0 \\
\hline & & Total & 60 & 100.0 \\
\hline 2 & Gender & Male & 24 & 40.0 \\
\hline & & Female & 36 & 60.0 \\
\hline & & Total & 60 & 100.0 \\
\hline 3 & Educational & Diploma & 16 & 26.7 \\
\hline & Qualification & Graduation & 18 & 30.0 \\
\hline & & Post Graduation & 18 & 30.0 \\
\hline & & Others & 8 & 13.3 \\
\hline & & Total & 60 & 100.0 \\
\hline 4. & Marital Status & Married & 48 & 80.0 \\
\hline & & Unmarried & 12 & 20.0 \\
\hline & & Total & 60 & 100.0 \\
\hline 5. & Occupational & Private Sector Employee & 38 & 63.3 \\
\hline & Status & Public Sector Employees & 6 & 10.0 \\
\hline & & Professionals & 16 & 26.7 \\
\hline & & Others & - & - \\
\hline & & Total & 60 & 100.0 \\
\hline 6. & Monthly & Rs.10000-20000 & 18 & 30.0 \\
\hline & Income Level & Rs.20001-30000 & 18 & 30.0 \\
\hline & & Rs.30001-40000 & 8 & 13.3 \\
\hline & & Above Rs.40000 & 16 & 26.7 \\
\hline & & Total & 60 & 100.0 \\
\hline
\end{tabular}

Source: Primary Data

Table 2. Financial literacy level of the households

\begin{tabular}{llcc}
\hline S. No & Financial Literacy & No. of. Respondents & Percentage \\
\hline 1. & Very High & 6 & 10.00 \\
2. & High & 14 & 23.33 \\
3. & Moderate & 22 & 36.67 \\
4. & Low & 10 & 16.67 \\
5. & Very Low & 8 & 13.33 \\
& Total & $\mathbf{6 0}$ & $\mathbf{1 0 0}$ \\
\hline
\end{tabular}

Source: Primary Data

whereas 23.33 per cent of them exhibited a high degree of financial literacy, 10 percent of the respondents had a very high level of financial literacy, while the remaining 30 per cent of them lacked proper financial literacy. On the score of saving and investment practices, it is found that all the
100 per cent of the respondents were holding saving bank accounts, followed by investment in own life policies and in share market (equity) by a maximum of 33.33 per cent and 30 per cent of them respectively. During the survey, majority of the sample respondents confessed that they 
Table 3. Nature of saving and investment practices among the respondents

\begin{tabular}{llcc}
\hline S. No & Factors & $\begin{array}{c}\text { No. of. Respondents } \\
(\mathrm{N}=60)\end{array}$ & $\begin{array}{c}\text { Proportionate } \\
\text { Percentage }\end{array}$ \\
\hline 1. & Bank Saving Accounts & 60 & 100 \\
2. & Bank Deposits (Fixed /Recurring) & 4 & 6.67 \\
3. & National Saving Certificates & 4 & 6.67 \\
4. & Post Office Savings & 14 & 23.33 \\
5. & Private Chits & 10 & 16.67 \\
6. & Mutual Funds & 16 & 26.67 \\
7. & Life Insurance & 20 & 33.33 \\
8. & Share Market (Equity) & 18 & 30.00 \\
9. & Real Estates & 10 & 16.67 \\
10. & Gold / Bullions & 10 & 16.67 \\
\hline Source: & Primary Data
\end{tabular}

Source: Primary Data

Table 4. Chi-square result and goodness of fit indices of the proposed model

\begin{tabular}{|c|c|c|c|}
\hline Fit Indices & $\begin{array}{l}\text { Obtained } \\
\text { Value }\end{array}$ & $\begin{array}{c}\text { Accepted } \\
\text { Thresholds Levels }\end{array}$ & Acceptable Value \\
\hline$\chi^{2}$ & 78.560 & $\mathrm{NA}$ & NA \\
\hline Scaled $\chi^{2} / \mathrm{df}$ & .000 & $<0.05$ & $<0.05$ \\
\hline $\begin{array}{l}\text { Goodness of Fit Index } \\
\text { (GFI) }\end{array}$ & .756 & $\begin{array}{l}\text { Value Greater } \\
\text { than } 0.95\end{array}$ & $0-1$ \\
\hline $\begin{array}{l}\text { Adjusted Goodness of Fit } \\
\text { Index(AGFI) }\end{array}$ & .390 & $\begin{array}{l}\text { Value Greater } \\
\text { than } 0.95\end{array}$ & $0-1$ \\
\hline Tucker-Lewis Index (TLI) & .294 & $\begin{array}{l}\text { Value Greater } \\
\text { than } 0.95\end{array}$ & $0-1$ \\
\hline $\begin{array}{l}\text { Comparative Fit Index } \\
\text { (CFI) }\end{array}$ & .577 & $\begin{array}{l}\text { Value Greater } \\
\text { than } 0.95\end{array}$ & $0-1$ \\
\hline Normed Fit Index (NFI) & .567 & $\begin{array}{l}\text { Value Greater } \\
\text { than } 0.95\end{array}$ & $0-1$ \\
\hline $\begin{array}{l}\text { Parsimonious Normed Fit } \\
\text { Index (PNFI) }\end{array}$ & .340 & $\begin{array}{l}0=\text { Poor Fit } \\
1=\text { Good Fit }\end{array}$ & $0-1$ \\
\hline $\begin{array}{l}\text { Parsimony Comparative Fit } \\
\text { Index (PCFI) }\end{array}$ & .346 & $\begin{array}{l}0=\text { Poor Fit } \\
1=\text { Good Fit }\end{array}$ & $0-1$ \\
\hline Relative Fit Index (RFI) & .278 & $\begin{array}{l}0=\text { Poor Fit } \\
1=\text { Good Fit }\end{array}$ & $0-1$ \\
\hline Incremental Fit Index (IFI) & .586 & $\begin{array}{l}0=\text { Poor Fit } \\
1=\text { Good Fit }\end{array}$ & $0-1$ \\
\hline $\begin{array}{l}\text { Root Mean Square } \\
\text { Approximation Method } \\
\text { (RMSEA) }\end{array}$ & .000 & Value less than 0.07 & $\begin{array}{c}.05 \text { or less would } \\
\text { indicate a close fit } \\
\text { of the model }\end{array}$ \\
\hline
\end{tabular}

estimate their family needs in terms of money and based on their requirements they plan their saving or investments and however, at least 30 per cent of the respondents opined that they could save only a minor part of their earnings after meeting all the household expenses. The study has divulged that there exists a close association between financial literacy level of households, their current financial conditions, nature of saving and investment practices and financial discipline practices, and that of their perception on influences of job on their financial status. 
Table 5. Path analysis structure maximum likelihood -regression weightage

\begin{tabular}{lccccccccc}
\hline H0 & & Path & & $\begin{array}{c}\text { Unstandardized } \\
\text { Estimates }(\beta)\end{array}$ & S.E & C.R & P. Value & Relationship & Results \\
\hline H1 & IJOFC & $<---$ & FINLT & .149 & .049 & 3.019 & .003 & Significant & $\begin{array}{c}\text { Positive / } \\
\text { Confirmed }\end{array}$ \\
H2 & IJOFC & $<---$ & CFINC & -.990 & .134 & -7.368 & 000 & Significant & $\begin{array}{c}\text { Positive / } \\
\text { Confirmed }\end{array}$ \\
H3 & IJOFC & $<---$ & NOSAI & 3.265 & .087 & -27.729 & 000 & Significant & $\begin{array}{c}\text { Positive / } \\
\text { Confirmed } \\
\text { Positive / }\end{array}$ \\
H4 & IJOFC & $<---$ & FINDP & -2.421 & .121 & 27.074 & 000 & Significant & \begin{tabular}{c} 
Confirmed \\
\hline
\end{tabular} \\
\hline
\end{tabular}

Level of Significance: 5 Per cent

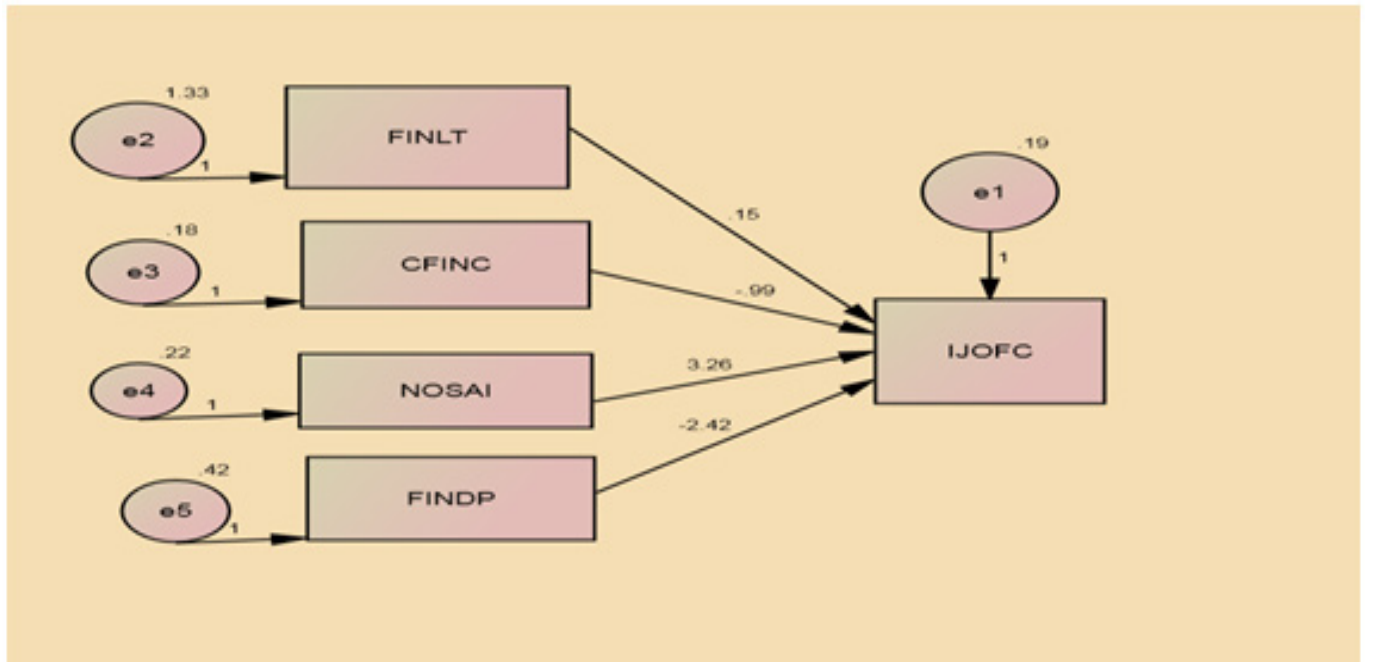

Exhibit 1. Structural equation modeling analysis goodness of fit model.

\section{Suggestions}

As the study reveals that there exists a close relation between financial literacy level of households or individuals, their current financial conditions, their financial discipline practices and their savings and investment practices, and that of their perception on influences of job, the financial management practices become more important for the individuals. They need money to meet various financial obligations and hence to manage the financial resources effectively to maintain a good financial condition, individuals must have adequate knowledge about various financial products and profitable investment avenues. They must know about the interest rate, inflation rate, compound interest and the risk involved in it. Irrespective of the job status, saving habits among the individuals promote their economic growth and it will give them adequate financial freedom. The individuals must have basic money management skills like tracking the expected and unexpected expenses and investing their surplus money in diversified alternatives.

\section{Conclusion}

In reality money is considered as motivating factor behind every individual in selection or professing a particular occupation. Individual differences and the people's tendency to think or worry about money are different and people value money for different reasons (e.g., as a means to power, freedom, security, or love). There is a correlation between income and well-being at any given point in time. However, because of habituation, increases in income do not appear to equate to increases in well-being in the long term and conversely decreases in income do appear to equate to decreases in well-being.

In both government and private organizations, it is very essential to understand the want of their employees in terms of financial remuneration and to understand how really their employees value their salary in terms of money. Influences of job on the employees including private sector workers' life-style and socio-economic status are more related to emotional feel. Wise investment pattern and 
strategic financial planning can support both self-employed persons and employees working in either public or private sectors in enhancing their current financial conditions. Studies related to this concept are scarer as far as Indian context is considered and hence there is a wide scope for conducting of more studies in future too.

\section{References}

1. Mustapha N. The influence of financial reward on job satisfaction among academic staffs at public universities in Kelantan, Malaysia. International Journal of Business and Social Science. 2013 Mar; 4(3):244-8.

2. Cohen M. Sebstad J. Financial education for the poor. Working Paper, Microfinance Oppurtunities, Washington, DC; 2003. Available from: www.microfinanceopportunities. org

3. Joo S, Grable JE. An exploratory framework of the determinants of financial Satisfaction. Journal of Family and Economic Issues. 2004; 25(1):162-71. Available from: http:// dx.doi.org/10.1023/B:JEEI.0000016722.37994.9f

4. Tedeschi RG, Calhoun LG. Posttraumaticgrowth: Conceptual foundations and empirical evidence; 2004. Available from: http://dx.doi.org/10.1207/s15327965pli1501_

5. Neill B, Xiao JJ, Sorhaindo ETB. Financially distressed consumers: Their financial practices, financial well-being, and health. Financial Counseling and Planning; 2005.

6. Caskey J. Can personal financial management education promote asset accumulation by thepoor? Networks Financial Institute Policy Brief No. 2006-PB-06; 2006. Available from SSRN: http://ssrn.com/abstract $=923565$

7. Tamimi AH, Kalli AB. Financial literacy and investment decisions of UAE investors. The Journal of Risk Finance. 2009; 10(5).

8. Holzmann R. Bringing financial literacy and education to low and middle income countries: The need to review, adjust, and extend current wisdom. World Bank, IZA and CES,
2010. Available from: http://erepository.uonbi.ac.ke:8080/ xmlui/handle/123456789/9897

9. Cude BJ. Financial literacy. The Journal of ConsumerAffairs. 2010; 44(2).

10. Mc Carthy. Behavioral characteristics and financial distress. European Central Bank Working Paper Series, No1303/F; 2011 Feb. Available from: http://ssrn.com/abstract_ id $=1761570>$

11. Marican S, Btezakaria R, Abdulrahman A. Stressed employees at workplace: A Malaysian Perspective. International Journal of Research in Social Sciences. 2012; 2(2). Available from: http://www.ijmra.us

\section{Other References}

1. NCAER Saving in India, 1950-51 to 1961-62. New Delhi; 1960.

2. Kothari CR. Research methodology methods and techniques. Available from: www.newagepublishers.com

3. Gitman LJ. Personal finance. IIIinosis: Dr Yden Press; 1981.

4. Lau CM, Sholihin M. Financial and nonfinancial performance measures: How do they affect job satisfaction? The British Accounting Review. 2005; 37:389-413. Available from: http://dx.doi.org/10.1016/j.bar.2005.06.002

5. Chi CG, Gursoy D. Employee satisfaction, customer satisfaction and financial performance: An empirical examination. International Journal of Hospitality Management. 2009; 28:245-53. Available from: http://dx.doi.org/10.1016/j. ijhm.2008.08.003.

6. Kapur D, Vaishnav M. Being middle class in India. The Hindu; 2014 Jan $10^{\text {th }}$. Available from: http://www.thehindu.com/ opinion/op-ed/being-middle-class-in-india/article6673580. ece

7. Yoo K-B, Park E-C, Jang S-Y, Kwon JA, Kim SJ, Cho K-H, Choi J-W, Kim J-H, Park S. Association between employment status change and depression in Korean adults. BMJ. 2016; 6(3). Available from: http://bmjopen.bmj.com/content/6/3/ e008570 